Provided for non-commercial research and education use. Not for reproduction, distribution or commercial use.

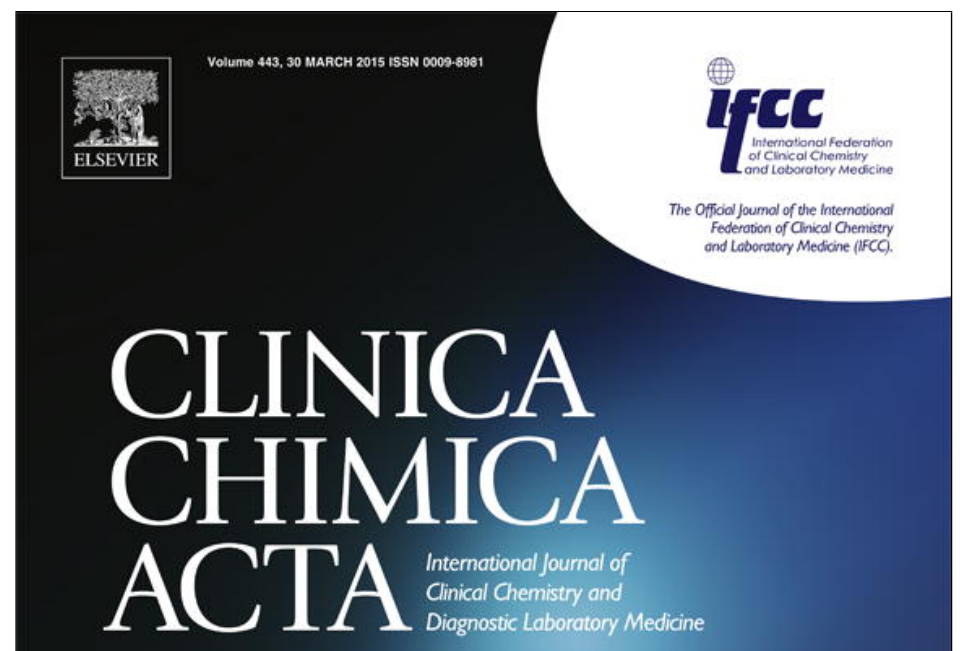

Special Issue

Biomarkers in Heart Failure

Guest Editors:

M. De Buyzere

D. Gruson

This article appeared in a journal published by Elsevier. The attached copy is furnished to the author for internal non-commercial research and education use, including for instruction at the authors institution and sharing with colleagues.

Other uses, including reproduction and distribution, or selling or licensing copies, or posting to personal, institutional or third party websites are prohibited.

In most cases authors are permitted to post their version of the article (e.g. in Word or Tex form) to their personal website or institutional repository. Authors requiring further information regarding Elsevier's archiving and manuscript policies are encouraged to visit:

http://www.elsevier.com/authorsrights 


\title{
Markers of fibrosis, inflammation, and remodeling pathways in heart failure
}

\author{
Claudio Passino ${ }^{\mathrm{a}, \mathrm{b}, *}$, Andrea Barison $^{\mathrm{a}}$, Giuseppe Vergaro ${ }^{\mathrm{a}}$, Alessandra Gabutti ${ }^{\mathrm{a}}$, Chiara Borrelli ${ }^{\mathrm{b}}$, \\ Michele Emdin ${ }^{\mathrm{a}}$, Aldo Clerico ${ }^{\mathrm{b}}$ \\ a Division of Cardiology and Cardiovascular Medicine, Fondazione G. Monasterio CNR-Regione Toscana, Italy \\ b Scuola Superiore Sant'Anna, Pisa, Italy
}

\section{A R T I C L E I N F O}

\section{Article history:}

Received 25 June 2014

Received in revised form 22 August 2014

Accepted 3 September 2014

Available online 10 September 2014

\section{Keywords:}

Heart failure

Remodeling

Fibrosis

\begin{abstract}
A B S T R A C T
Ventricular remodeling occurs progressively in untreated patients after large myocardial infarction and in those with cardiomyopathy. The pathologic changes of increased left ventricular (LV) volume and perturbation in the LV chamber geometry involve not only the myocytes, but also the non-myocyte cells and the extracellular matrix. Inflammation, fibrosis, neuro-hormonal activation, and ongoing myocardial damage are the mechanisms underlying remodeling. The detection of an ongoing remodeling process by means of biomarkers such as cytokines, troponins, neurohormones, metalloproteinases, galectin-3, ST-2 and others, may hold a clinical value and could, to some extent, drive the therapeutical strategy in patients after a myocardial infarction or with heart failure. For this reason, there is an increasing interest in the development of new biomarkers and a great number of laboratory tests have been recently proposed, whose clinical usefulness, however, is not fully established yet.
\end{abstract}

(C) 2014 Elsevier B.V. All rights reserved.

\section{Introduction}

Heart failure (HF) has long been considered as an irreversible disease, willing only to receive palliative therapy. However, the idea of chronic HF as an irreversible, end-stage process has been challenged by experimental and clinical evidence that early pharmacological intervention may lead to improvement in the function and structure of the failing heart [1]. Several biohumoral markers have been proposed for the diagnosis of HF so far [2], natriuretic peptides and troponins being the most widely tested and validated in this clinical setting. Besides early diagnosis, evaluation of the ongoing remodeling process has challenged clinicians and a specific, accurate, and effective biomarker of this process is still an unmet need (Fig. 1). For this reason, there is an increasing interest in the development of novel biomarkers and a great number of laboratory tests have been recently proposed, whose clinical usefulness, however, is not fully established yet [2].

As a matter of fact, in the last international guidelines on the management of HF only 3 groups of biomarkers were taken into account: natriuretic peptides (in particular BNP and NT-proBNP both for diagnostic and prognostic purposes with class I recommendation), markers of myocardial injury (i.e., cardiac troponin I and T, with class I recommendation),

* Corresponding author at: Division of Cardiology and Cardiovascular Medicine, Fondazione Toscana Gabriele Monasterio CNR-Regione Toscana, Via Giuseppe Moruzzi 1, 56124 Pisa, Italy. Tel: + 390503152191 ; fax: + 390503152109

E-mail address: passino@ftgm.it (C. Passino). and markers of myocardial fibrosis (such as galectin-3 and sST2, mainly for risk stratification with class IIb recommendation) [3] (Table 1). Of course, these recommendations are supported mainly by scientific evidences based on the results of well-designed randomized clinical trials, which demonstrated the good diagnostic and prognostic efficiency, as well as the favorable cost/benefit ratio for HF patients and community of these biomarkers $[2,4,5]$. However, some methodological considerations should also be taken into account, when a novel biomarker is recommended for clinical laboratory practice or large population screening. As an example, a list of some desirable characteristics for an ideal biomarker, recommended for the routine use in a clinical laboratory, are reported in Table 2.

Another aspect that should be preliminarily underscored is the heterogeneity of the HF syndrome, in terms of etiology, pathophysiology and clinical presentation: this may account for the wide differences in response to treatment and, therefore, in survival among patients who received a diagnosis of HF. As an example, HF may be associated with reduced (i.e. $<40 \%$ ) ejection fraction ( $\mathrm{HFrEF}$ ) or with preserved ejection fraction (HFpEF), resulting in similar symptoms and signs, but with profound differences in pathophysiology and response to treatment [3]. Patients with HFrEF have a higher risk of death than patients with HFpEF, [6], but absolute mortality is still high in the latter group. Randomized controlled trials have mainly enrolled patients with HFrEF, and it is only in these patients that efficacious therapies have been demonstrated to date [3]. In addition the diagnosis of HFpEF is challenging and generally posed after excluding other potential noncardiac causes of symptoms 


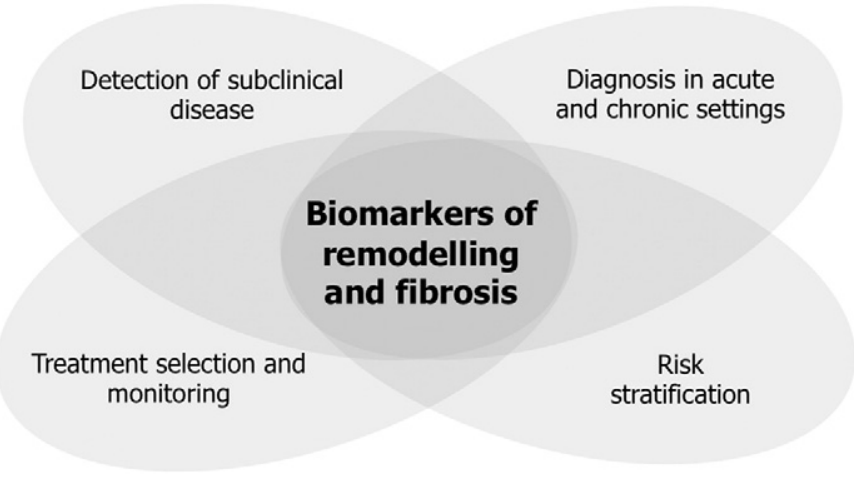

Fig. 1. Potential clinical usefulness of biomarkers of fibrosis and remodeling.

suggestive of HF. To date, efficacious therapies have not been identified for $\operatorname{HFpEF}[7,8]$

The aim of this review article is to provide a general overview on the biomarkers of the different pathways involved in the remodeling process.

\section{Cardiac remodeling}

$\mathrm{HF}$ is the final result of several etiologies (ischemic heart disease accounting for roughly half of cases) and includes heterogeneous patients with diverse propensity to ventricular remodeling and clinical outcome [9]. Despite optimized medical therapy and technologically advanced device treatment, the majority of patients affected by HF experience progressive left ventricular dysfunction, worsening of symptoms and life-threatening arrhythmias. Cardiac death occurs because of arrhythmic event or pump failure, and mid and long term survival is still disappointing (9) (Fig. 2). Following the initial decline of left ventricular (LV) contractility, patients with $\mathrm{HF}$ can remain asymptomatic (stage B of ACCF/AHA classification) or paucisymptomatic (stage C) for years, as the result of the compensatory mechanisms sustaining cardiovascular function. However, these mechanisms promote complex structural and functional abnormalities of the myocyte and non-myocyte cells, contributing to LV enlargement and dysfunction (adverse remodeling). In particular, biomolecular remodeling [10], cardiomyocyte hypertrophy and extensive extracellular matrix production [11-13] may be promoted not only by the original noxa (i.e. necrosis, virus, toxics, autoimmunity), but also by chronic mechanical overload, myocardial ischemia due to microvascular dysfunction [14-16], and sustained activation of neurohormonal and cytokine systems [17]. From a clinical point of view, it is crucial to identify the subgroup of asymptomatic patients at higher risk, who need a more strict follow-up and an enhanced therapeutic effort, especially in the early HF stages (A and B) of disease, when the clinical status and LV function are yet poor predictors of disease evolution and clinical outcomes [18].

Myocardial remodeling in ischemic and nonischemic cardiomyopathies involves not only the myocytes, but also the non-myocyte cells and the extracellular matrix (ECM). ECM constitutes around 6\% of the normal heart and includes fluid, collagen and glycoproteins. In particular,

Table 1

Established biomarkers for HF management.

Adapted from 2013 ACCF/AHA Heart Failure Guidelines [3].

\begin{tabular}{lllll}
\hline Biomarker & Setting & Application & Class & Evidence \\
\hline BNP/NT-proBNP & Acute/chronic & Diagnosis & I & A \\
BNP/NT-proBNP & Acute/chronic & Risk stratification & I & A \\
BNP/NT-proBNP & Chronic & Guide for treatment & IIa & B \\
BNP/NT-proBNP & Acute & Guide for treatment & IIb & C \\
Troponins & Chronic & Risk stratification & I & A \\
Soluble ST2 & Acute/chronic & Risk stratification & IIb & A/B \\
Galectin-3 & Acute/chronic & Risk stratification & IIb & A/B \\
\hline
\end{tabular}

collagen is secreted by fibroblasts as procollagen into the ECM, where protease enzymes remove amino and carboxy-propeptide terminals, and is then broken down by matrix metalloproteinase enzymes, which are in turn regulated by their tissue inhibitors. In pathological conditions, the cardiac interstitium increases as a result of diffuse interstitial (microscopic) fibrosis, post-necrotic replacement (macroscopic) fibrosis, myocardial edema (as result of inflammatory processes) or pathological infiltration (e.g. amyloid). The activation of the renin-angiotensin-aldosterone system plays a central role in fibroblast activation and collagen deposition, with the transforming growth factor $\beta$ (TGF $\beta$ ) as the downstream signal mediator. Endomyocardial biopsy still represents the current reference method for the evaluation of the remodeling process at a cellular level, although routine endomyocardial biopsy is not recommended in all cases of $\mathrm{HF}$ [3], but some circulating cardiac biomarkers may provide unique information regarding cardiovascular remodeling. Indeed, along the complex path from risk to fully developed $\mathrm{HF}$, there are increasing numbers of injury, remodeling and neurohormonal activation substances discovered, whose assays might provide important information about HF. Some, as natriuretic peptides and troponins, are well validated and established according to evidence-based laboratory medicine principles [3-5], while several other biomarkers are still being explored for potential use in the clinical practice.

\section{The pathophysiological role of cytokines in myocardial fibrosis}

Inflammation mechanisms should be considered as an essential component of the normal wound healing process [19-22]. However, when the injury cannot be repaired in a short time, a chronic inflammatory response may be established. In this case, a chronic inflammatory response allows a pathological wound repair, with accumulation of permanent fibrotic tissue at the site of injury. The final result of this dysregulated inflammatory process is the impossibility for the tissue to restore the normal function.

Fibrosis can affect any organ including the lung, skin, heart, kidney and liver and it is estimated that $45 \%$ of deaths in the western world can now be attributed to diseases where fibrosis plays a major pathophysiological role [19]. In particular, the clinical syndrome of HF is characterized by a systemic inflammatory response that contributes to end organ damage in the heart and circulation and thus, can lead to progressive worsening of cardiovascular function. The inflammatory mediators in HF patients include pro-inflammatory cytokines and their cognate receptors, as well as molecules secreted/released by macrophages (such as galectin-3 and pentraxin-3-PTX3) [21]. Inflammatory biomarkers usually correlate with disease severity and prognosis across the broad spectrum of HF syndromes [21-23].

Levine et al. [23] reported for the first time that HF patients usually show elevated circulating levels of tumor necrosis factor (TNF). Further studies have then expanded this observation by demonstrating that proinflammatory cytokines and their receptors, cell adhesion molecules, and chemokines are elevated in patients with HF with a decreased ejection fraction [9]. In addition, the most important pathophysiological mechanisms underlying HF with a preserved ejection fraction are fibrosis and reduced ventricular compliance, which in turn cause the development of left ventricular diastolic dysfunction. In Tables 3 and 4 we reported a list of these inflammatory agents, more frequently suggested as possible biomarkers for HF [19-24].

Inflammation is one of the earliest events in cardiac stress situations such as pressure and/or volume overload and involves elevated levels of endothelial/vascular (VCAM) and intercellular adhesion molecules (ICAM), as well as increased production and release of inflammatory cytokines and chemokines in the tissue [18-21,23]. Cytokines and chemokines recruit activated inflammatory cells, particularly monocytes, from circulation into the cardiac tissue. Increased monocyte infiltration is seen in the early and late stages of HF [23]. Once inside the cardiac tissue, monocytes differentiate into macrophages and promote inflammation, tissue injury, and fibrosis of myocardial tissue. Activated 
Table 2

Desirable features fitted by biomarkers measured by the laboratory test.

\begin{tabular}{|c|c|c|c|}
\hline Desirable feature of biomarker & Tests fitting the feature & Tests not fitting the feature or no available data & References \\
\hline Evaluation of in vivo and in vitro stability & cTnI, cTnT, NT-proBNP, BNP & MMP assay, cytokines assays, galectin-3, sST2 & {$[60,64,77,121]$} \\
\hline $\begin{array}{l}\text { Evaluation of analytical performance according } \\
\text { to the EBLM criteria }\end{array}$ & $\begin{array}{l}\text { cTnI, cTnT, NT-proBNP, BNP, } \\
\text { galectin-3, sST2 }\end{array}$ & MMP assay, cytokine assays & {$[2,3,5,21,77,118-121,123,124]$} \\
\hline Complete automation & cTnI, cTnT, NT-proBNP, BNP, galectin-3 & MMP assay, cytokine assays, sST2 & {$[2,60,64,77,118-120,122-125]$} \\
\hline Acceptable harmonization between methods & cTnT, NT-proBNP, galectin-3, sST2 & BNP, MMP assay, cytokine assays & {$[60,64,77,121]$} \\
\hline Evaluation of biological variation & cTnI, cTnT, BNP, NT-proBNP & MMP assay, cytokines assays, galectin-3, sST2 & {$[75,77]$} \\
\hline Cardiac specificity & cTnI, cTnT, BNP, NT-proBNP & MMP assay, cytokines assays, galectin-3, sST2 & {$[2,21,22,77]$} \\
\hline $\begin{array}{l}\text { Evaluation of reference interval tested for gender, } \\
\text { age and ethnicity dependence }\end{array}$ & cTnI, cTnT, BNP, NT-proBNP & MMP assay, cytokines assays, galectin- 3 , sST2 & {$[3,17,77,87]$} \\
\hline $\begin{array}{l}\text { Diagnostic and prognostic accuracy tested by large } \\
\text { randomized clinical trials according to the EBLM } \\
\text { criteria (level of evidence IA) }\end{array}$ & cTnI, cTnT, BNP, NT-proBNP & MMP assay, cytokines assays, galectin-3, sST2 & {$[2-4,21,22,77]$} \\
\hline $\begin{array}{l}\text { Cost-benefit ratio favorable tested by randomized } \\
\text { clinical trials }\end{array}$ & cTnI, cTnT, BNP, NT-proBNP & MMP assay, cytokines assays, galectin-3, sST2 & {$[2-4,77]$} \\
\hline
\end{tabular}

Cytokine assays include all the immunoassays for the interleukin/cytokine superfamilies (such TNF, IL-1, IL-2, IL-6).

macrophages produce and secrete several inflammatory mediators, such as monocyte chemotactic protein-1 (MCP1) and TNF-alpha (TNF$\alpha$ ), and fibrogenic activators, such as TGF- $\beta$, and in this way support pro-inflammatory and pro-fibrotic processes $[24,25]$. Activated macrophages also secrete galectin-3, which may induce cardiac fibroblast proliferation, collagen deposition, and ventricular dysfunction [26,27]. PTX3 is a novel inflammatory marker and member of the pentraxin superfamily of cytokines, which has also recently been identified in patients with HF [21]. PTX3 synthesis is produced/released by endothelial cells, macrophages, myeloid cells, and dendritic cells stimulated by cytokines and endotoxins such as bacterial products, interleukin-1 (IL-1), and TNF $[21,28]$.

According to the pathophysiological mechanisms reported above, circulating levels of the inflammatory mediators and agents are found with increasingly higher concentrations in the blood from HF patients with asymptomatic left ventricular dysfunction [29] to those with more severe disease according to the NYHA functional class [30]. In particular, soluble type 1 and type 2 TNF receptors (sTNFR1 and STNFR2, respectively) and soluble transmembrane glycoprotein 130 (gp130, one of the receptors related to the IL-6) are increased according to worsening HF functional class [21,22]. Furthermore, elevated circulating levels of some pro-inflammatory cytokines correlate not only with disease severity, but also with increased mortality in HF patients [21,22]. In particular, TNF, IL-6, sTNFR1, and sTNFR2 have been reported to be associated to increased mortality [31,32]. There are relatively few studies, which evaluated the prognostic relevance of pro-inflammatory cytokine levels in HF patients with preserved ejection fraction: only TNF levels have been shown to correlate with increased mortality in this setting [33].

Growth differentiation factor 15 (GDF15), a member of the transforming growth factor-beta cytokine superfamily, is another marker of cell injury and inflammation that has been shown to circulate in higher concentrations in patients with HFrEF with reduced ejection fraction [34,35] and also in HFpEF [36], compared with controls. In a more recent study, GDF15 was shown to be able to discriminate HFpEF from controls at least as well as NT-proBNP [37] and the ratio of NT-proBNP to GDF15 provided the best discriminatory ability between HFpEF and HFrEF [37].

Finally, increased levels of some inflammatory mediators were found to be significantly associated with disease severity and prognosis also in patients with acute decompensated HF [3]. In particular, Creactive Protein (CRP), ST-2, galectin-3, and IL-6 showed a significant association with an increased mortality rate in patients with acute $\mathrm{HF}$ [38-44]. However, inflammatory biomarkers alone show much lower diagnostic and prognostic accuracy than natriuretic peptides in HF patients admitted with acute dyspnea in emergency department [21,42].

\section{Biomarker of ECM}

The ECM in the healthy heart is dynamic and can adapt to differing environmental factors [45]. In pathological states, it can increase as a result of diffuse myocardial fibrosis (reactive or interstitial fibrosis, secondary to mechanical, toxic, infective or autoimmune insults) or of
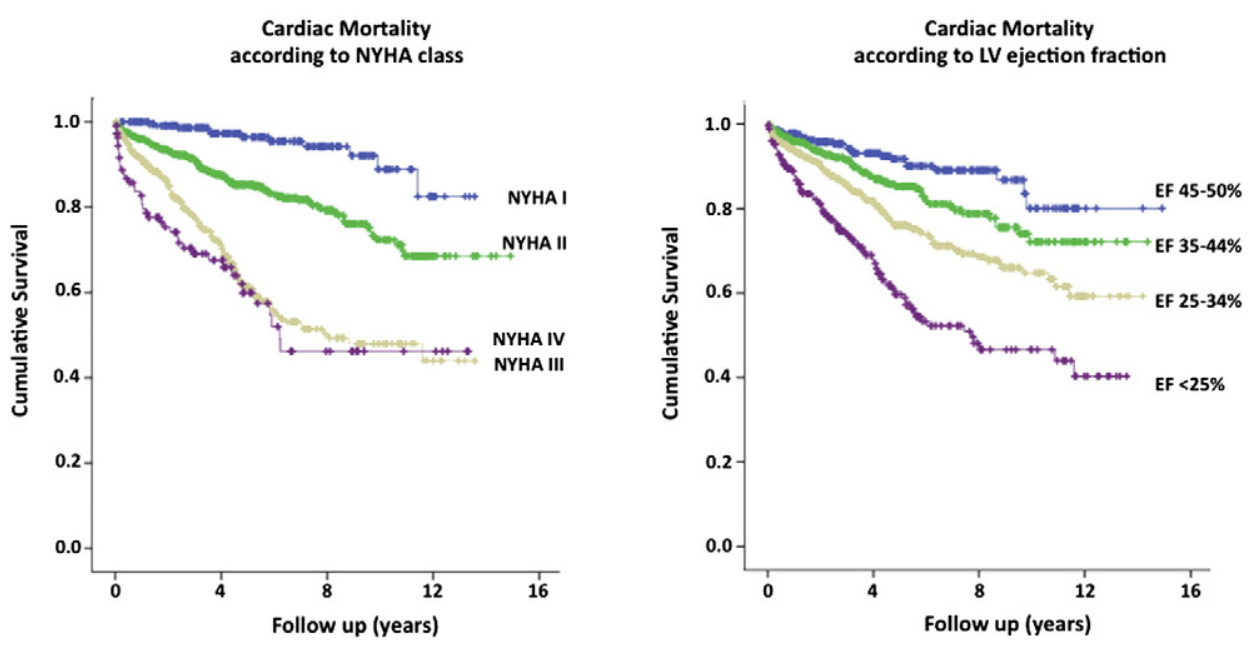

Fig. 2. Survival plots in the Pisa cohort of systolic heart failure patients ( $N=1546$ patients) on optimal medical therapy, according to the New York Heart Association (NYHA) classification (left) or to the left ventricular ejection fraction (right); cardiac death was considered as an end-point. 
Table 3

Some biochemical and physiological characteristics of TNF superfamily cytokines and other pro-inflammatory and regulatory cytokines suggested as biomarkers for heart failure.

\begin{tabular}{|c|c|c|c|}
\hline Biomarker & $\mathrm{MW}(\mathrm{kDa})^{\mathrm{a}}$ & Biochemical structure & Biological characteristics \\
\hline TNF superfamily & & & $\begin{array}{l}\text { The TNF superfamily currently consists of } 19 \text { ligands and } 29 \text { receptors in humans. Most TNF } \\
\text { ligands are type II transmembrane proteins whose extracellular domains can be cleaved by } \\
\text { specific metalloproteinases to generate soluble cytokines. TNF superfamily ligands and } \\
\text { receptors play a role in normal developmental processes, apoptosis, regulation of immune } \\
\text { cell functions, and also in cancer and autoimmune diseases. }\end{array}$ \\
\hline TNFa & $\begin{array}{l}\text { About } 17 \mathrm{kDa} \\
\text { (recombinant, mouse) }\end{array}$ & $\begin{array}{l}156 \text { aa protein (recombinant } \\
\text { mouse) }\end{array}$ & Adipokine/cytokine involved in systemic inflammation and the acute phase reaction \\
\hline TWEAK (TNFSF12) & $\begin{array}{l}\text { About } 17 \text { kDa soluble } \\
\text { protein (recombinant, } \\
\text { human) }\end{array}$ & $\begin{array}{l}249 \text { aa membrane protein, } \\
156 \text { aa soluble protein }\end{array}$ & Transmembrane and soluble (cytokine) protein of the TNF ligand superfamily. \\
\hline $\begin{array}{l}\text { FasL (TNFSF6 or } \\
\text { CD95L) }\end{array}$ & $\begin{array}{l}\text { About } 40 \mathrm{kDa} \text { as a } \\
\text { tramsmenbrane protein } \\
\text { (human) } \\
\text { About } 18 \mathrm{kDa} \text { as a soluble } \\
\text { protein (recombinant, } \\
\text { human) }\end{array}$ & $\begin{array}{l}157 \text { aa soluble protein } \\
\text { (recombinant, human) }\end{array}$ & Transmembrane and soluble protein of the TNF ligand superfamily \\
\hline $\begin{array}{l}\text { LIGHT (TNFSF14 or } \\
\text { CD258) }\end{array}$ & $\begin{array}{l}\text { About } 23 \mathrm{kDa} \\
\text { (recombinant, human) }\end{array}$ & 183 aa (recombinant, human) & Member of the TNF ligand superfamily, which acts as a ligand for TNFRSF14 \\
\hline $\begin{array}{l}\text { Pro-inflammatory } \\
\text { and regulatory } \\
\text { cytokines }\end{array}$ & & & $\begin{array}{l}\text { A pro-inflammatory cytokines are agents promoting systemic inflammation (such as IL-1 } \\
\text { and TNF). Regulatory cytokines include IL-2, IL-4, IL-7, IL-9, IL-15 and IL-21, which play a } \\
\text { role in the maturation of lymphocytes. }\end{array}$ \\
\hline$I L-1 \beta$ & $\begin{array}{l}17.4 \mathrm{kDa} \text { (recombinant, } \\
\text { mouse) } \\
17.4 \mathrm{kDa} \text { (recombinant, } \\
\text { human) }\end{array}$ & $\begin{array}{l}152 \text { aa (recombinant, mouse) } \\
153 \text { aa (recombinant, human) }\end{array}$ & $\begin{array}{l}\text { IL- } 1 \beta \text { is a member of the interleukin } 1 \text { family of cytokines, which is an important mediator } \\
\text { of the inflammatory response, and is involved in a variety of cellular activities (such as cell } \\
\text { proliferation, differentiation, and apoptosis). }\end{array}$ \\
\hline IL-2 & $\begin{array}{l}15.3 \mathrm{kDa} \text { (recombinant, } \\
\text { human) }\end{array}$ & About 134 aa & $\begin{array}{l}\text { IL-2 is a regulatory cytokine necessary for the growth, proliferation, and differentiation of } \\
\text { thymic-derived lymphocytes (T cells) to become 'effector' T cells. }\end{array}$ \\
\hline IL-6 & $23.7 \mathrm{kDa}$ (human) & 212 aa (human) & $\begin{array}{l}\text { IL-6 is a pro-inflammatory cytokine, secreted by macrophages and T cells to stimulate } \\
\text { immune response during infection, trauma, and burns. }\end{array}$ \\
\hline IL-18 & $\begin{array}{l}18 \mathrm{kDa} \text { (recombinant, } \\
\text { human) }\end{array}$ & 157 aa (recombinant, human) & $\begin{array}{l}\text { IL- } 18 \text {, also known as interferon-gamma inducing factor, is a proinflammatory cytokine of } \\
\text { the IL-1 superfamily. }\end{array}$ \\
\hline IL-33 & $\begin{array}{l}18 \mathrm{kDa} \text { (recombinant, } \\
\text { human) }\end{array}$ & 159 aa (recombinant, human) & $\begin{array}{l}\text { IL-33 is a proinflammatory cytokine expressed on a wide variety of cell types, including } \\
\text { fibroblasts, mast cells, dendritic cells, macrophages, osteoblasts, endothelial cells, and } \\
\text { epithelial cells. }\end{array}$ \\
\hline
\end{tabular}

FasL: Fas ligand; LIGHT, an acronym derived from: homologous to Lymphotoxins, Inducible expression, competes with HSV Glycoprotein D for HVEM, a receptor expressed on T-lymphocytes;

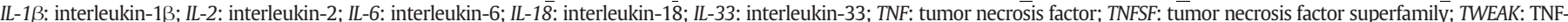
like weak inducer of apoptosis.

a The values of MW reported in the table are only indicative because several circulating and tissue isoforms of the same protein are present in humans.

Table 4

Biochemical and physiological characteristics of some cytokine receptors and macrophage products suggested as biomarkers for heart failure.

\begin{tabular}{|c|c|c|c|}
\hline Biomarker & $\mathrm{MW}(\mathrm{kDa})^{\mathrm{a}}$ & Biochemical structure & Biological characteristics \\
\hline \multicolumn{4}{|l|}{ Cytokines receptors } \\
\hline $\begin{array}{l}\text { TNFR1 (TNFRSF1A or } \\
\text { CD120a) and sTNFR1 }\end{array}$ & $\begin{array}{l}18.3 \mathrm{kDa} \text { (sTNFR1 recombinant, } \\
\text { human) }\end{array}$ & $\begin{array}{l}162 \text { aa (sTNFR1 } \\
\text { recombinant, human) }\end{array}$ & $\begin{array}{l}\text { TNFR1 belongs to the TNFR superfamily of transmembrane proteins. STNFR1 (the } \\
\text { soluble form of the receptor) is capable of inhibiting TNFa and TNFb activities by } \\
\text { acting as a decoy receptor binding the TNF ligands }\end{array}$ \\
\hline $\begin{array}{l}\text { TNFR2 (TNFRAF1B or } \\
\text { CD120b) and STNFR2 } \\
\text { (soluble form) }\end{array}$ & $\begin{array}{l}24.5 \mathrm{kDa} \text { (TNFR1 recombinant, } \\
\text { human) }\end{array}$ & $\begin{array}{l}184 \text { aa (TNFR1 } \\
\text { recombinant, human) }\end{array}$ & TNFR2 is a lower activator of signaling pathways related to TNF compared to TNFR1. \\
\hline $\begin{array}{l}\text { gp130 (IL6ST, IL6-beta or } \\
\text { CD130a) and sgp130 }\end{array}$ & $103.5 \mathrm{kDa}$ (human) & 918 aa (human) & $\begin{array}{l}\text { gp130 is a transmembrane protein, which is the founding member of the class of all } \\
\text { cytokine receptors. }\end{array}$ \\
\hline$I L-1 R A(I L-1 F 3)$ & $\begin{array}{l}\text { About } 17 \mathrm{kDa} \text { (there are several } \\
\text { isoforms from } 16 \text { to } 18 \mathrm{kDa} \text { ) }\end{array}$ & $\begin{array}{l}143 \text { aa }(16 \mathrm{kDa}) \text { and } 152 \\
\text { aa }(17 \mathrm{kDa})\end{array}$ & $\begin{array}{l}\text { IL- } 1 \text { RA is the natural receptor antagonist of IL- } 1 \text { because it is able to bind the same } \\
\text { specific receptor of IL- } 1 \text {. }\end{array}$ \\
\hline ST2 (IL-1RL1) and SST2 & $\begin{array}{l}\text { About } 63 \mathrm{kDa} \text { (ST2 or IL-1RL1) } \\
39.5 \mathrm{kDa} \text { (recombinant, human } \\
\text { sST2) }\end{array}$ & $\begin{array}{l}556 \text { aa (ST2 or IL-1RL1) } 310 \\
\text { aa (recombinant, human } \\
\text { SST2) }\end{array}$ & $\begin{array}{l}\text { ST2 is a member of the interleukin } 1 \text { receptor family. The ST2 protein has two } \\
\text { isoforms: a soluble form (sST2) and a membrane-bound receptor form (ST2). The } \\
\text { ligand for ST2 is IL-33. }\end{array}$ \\
\hline \multicolumn{4}{|l|}{ Macrophage products } \\
\hline Galectin-3 & $26 \mathrm{kDa}$ (recombinant, human) & $\begin{array}{l}250 \text { aa (recombinant, } \\
\text { human) }\end{array}$ & $\begin{array}{l}\text { Galectin- } 3 \text { is a member of the lectin family, of which } 14 \text { mammalian galectins have } \\
\text { been identified. Galectin- } 3 \text { contains a carbohydrate-recognition-binding domain } \\
\text { which specifically binds the } \beta \text {-galactosides. Galectin- } 3 \text { plays a role in cell adhesion, } \\
\text { cell activation and chemoattraction, cell growth and differentiation, cell cycle, and } \\
\text { apoptosis. }\end{array}$ \\
\hline Pentraxin-3 & $\begin{array}{l}\text { About } 42 \mathrm{kDa} \text { (monomer, } \\
\text { human) }\end{array}$ & 381 aa (human) & $\begin{array}{l}\text { Pentraxin-3 is a member of the pentraxin superfamily, which is characterized by } \\
\text { cyclic multimeric structure. This protein is rapidly produced and released by several } \\
\text { cell types, in particular by mononuclear phagocytes, dendritic cells, fibroblasts and } \\
\text { endothelial cells in response to primary inflammatory signals. }\end{array}$ \\
\hline
\end{tabular}

gp130: glycoprotein 130; sgp130: soluble gp130; IL1-F: interleukin-1 family; IL-1RA: interleukin-1 receptor antagonist; IL-1RL1: interleukin-1 receptor-like-1; sST2: soluble ST2 receptor; STNFR1: soluble TNF type1 receptor; sTNFR2: soluble TNF receptor type 2; TNFSF: tumor necrosis factor superfamily; TNFSFR: tumor necrosis factor superfamily receptor.

a The values of MW reported in the table are only indicative because several circulating and tissue isoforms of the same protein are present in humans. 
replacement fibrosis (e.g. in response to a large loss of myocytes, such as in myocardial infarction) (Table 5). The ECM can also increase because of myocardial edema (in myocarditis) or infiltration (for example with amyloid protein), and its expansion has been shown to correlate with arrhythmias, sudden cardiac death and HF in a number of cardiac diseases [46].

Some enzymes and molecules involved in ECM metabolism may be assayed in the peripheral blood and are therefore promising biomarkers for the assessment of cardiac fibrosis and clinical management in HF patients. Collagen network is the main structural component of ECM, and collagen types I and III are the most abundantly expressed in the heart [47]. Collagen concentration is affected by different stimuli, such as ischemia, autocrine/paracrine factors, myocardial stretch, or inflammation, through the regulation of the expression of matrix metalloproteinases (MMPs) and tissue inhibitor of matrix metalloproteinases (TIMPs). In particular, MMP-1 and TIMP-1 are co-expressed in cardiac fibroblasts and are tightly regulated to maintain the architecture of the ECM. Indeed higher levels of both MMP- 1 and TIMP- 1 are detected in the coronary sinus compared to the peripheral blood in patients with cardiovascular diseases (e.g. hypertension) [48]. The balance between MMPs and TIMPs likely reflects the extent of collagen turnover and may therefore influence the progression of cardiac remodeling. Consistently, the serum MMP-1:TIMP-1 ratio is associated with the degree of left ventricular dilatation and systolic dysfunction. [48].

Carboxy-terminal and amino-terminal propeptides of collagens I (PICP and PINP) and III (PIICP and PIIINP), are cleaved during the conversion of procollagen molecules into mature collagen and are related to ECM synthesis. On the other hand MMPs - in particular MMP-1, MMP-2 and MMP-9 - are responsible for collagen digestion, collagen I carboxy-terminal telopeptide (ICTP) being the principal by-product $[49,50]$.

All the aforementioned molecules reach the blood and their circulating levels have been tested as biomarkers of ventricular fibrosis and remodeling in HF settings. In some biopsy studies about the association between serum biomarkers and myocardial collagen content, serum concentrations of PICP, PIIINP and ICTP were correlated with the fibrillar collagen fraction in the myocardium [51,52]. Among community-living older adults, PIIINP was associated with cardiovascular disease and heart failure [53]; both ICTP and PIIINP have been shown to be significantly associated with an adverse outcome in individuals at risk of developing HF (stages A-B) [54]. Serum PIIINP correlates well with its tissue analogue (i.e. collagen type III) [51] and significantly associated with clinical status and outcome in cohorts of patients with dilated cardiomyopathy of both ischemic and non-ischemic etiologies [51,55]. A prognostic role for ICTP has been also demonstrated in both the acute and chronic phases following myocardial infarction [56] and elevated ICTP plasma levels have been associated with a worse prognosis in HF [57]. The PICP/ICTP serum level ratio reflects the extent of collagen accumulation. Izawa and colleagues have reported that patients with dilated cardiomyopathy and a high PICP/ICTP ratio show more abundant perivascular fibrosis and interstitial fibrosis, as assessed by collagenspecific staining on cardiac bioptic samples [58]. Interestingly, in the

Table 5

Phenotypes of the cardiac fibrous tissue.

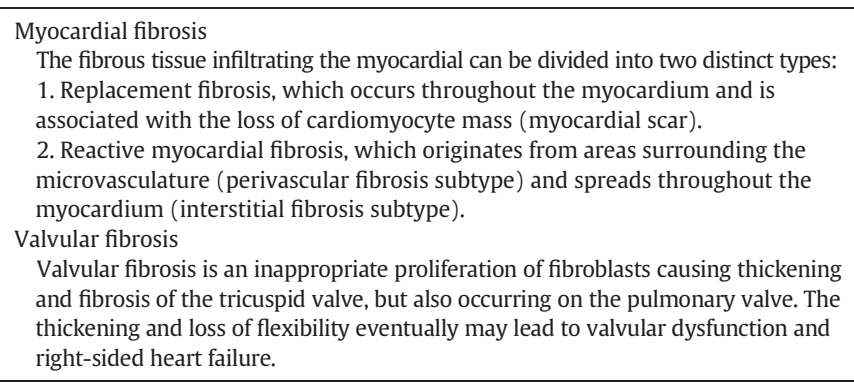

same study an increased diastolic left ventricular stiffness was also reported in patients with an elevated PICP/ICTP ratio. It could be hypothesized that ECM remodeling may indeed underlie the transition from subclinical cardiac damage and early stages $(\mathrm{A} / \mathrm{B})$ to clinically overt $\mathrm{HF}$ (stage C) either with or without reduced ejection fraction. Differential balances between MMP-1 and TIMP-1 (evaluated by the ratio of their circulating levels) seem to be specific of normotensive patients compared to hypertensive subjects who have developed HFpEF or HFrEF [59]. The MMP-1 to TIMP-1 ratio, measured in the peripheral vein blood, is correlated with left ventricular ejection fraction and enddiastolic diameter in an inverse and direct fashion, respectively. Further, plasma TIMP-1 was positively associated with left ventricular mass and wall thickness in a cohort of more than 1000 patients from the Framingham Heart Study [60], and predicts the presence of symptoms of congestive HF in hypertensive patients [61]. In recent years, the relationship between circulating ECM-associated molecules and left ventricular fibrosis and remodeling has been more and more often investigated by means of cardiac magnetic resonance; given the in vivo histological information this technique is able to provide. Eschalier et al. reported a correlation between early cardiac structural abnormalities, detected by magnetic resonance imaging, and PIIINP circulating concentration in obese patients [62].

Interestingly, antifibrotic treatment with mineralocorticoid receptor antagonists influences peripheral levels of biomarkers of ECM metabolism. In a subset of patients from the Randomized Aldactone Evaluation Study (RALES), PIIINP levels were decreased by treatment with spironolactone and identified those subjects with a significant prognostic benefit from the use of aldosterone antagonists [63], suggesting a potential value of this assay for tailoring medical treatment.

Although several studies support the potential clinical utility of ECM related biomarkers, their circulating levels are altered in several other extra-cardiac conditions, including cancer, bone diseases and inflammatory diseases, likely acting as confounding factors. Moreover, preanalytical issues should be taken into account in interpreting the assays of ECM related molecules. For example, significant higher values have been reported for serum compared to plasma MMP-9, due to the release of MMP-9 by polymorphonuclears during clot formation [64]. Finally, some difficulties still exist in comparing the results obtained using different commercial kits, given the lack of standardized assay procedures [60].

\section{The renin-angiotensin-aldosterone system, the transforming growth factor beta and cardiac fibrosis}

While myocyte hypertrophy has been demonstrated to be loaddependent, the activation of the renin-angiotensin-aldosterone system is a major determinant of fibroblast activation and collagen deposition [11], with the TGF- $\beta$ as the downstream signal mediator [65]. For instance, in animal models of high-output HF (e.g. arterio-venous fistula model of HF), the remodeling of the myocardium involves exclusively myocytes without relevant interstitial fibrosis, whereas in low-output HF models (e.g. pacing-induced HF), characterized by enhanced neurohormonal activation, extensive interstitial fibrosis is documented [66]. Angiotensin II partially mediates its effects through TGF- $\beta$, resulting in the upregulation of myocardial procollagens 1 and 3 production [67]: along with alterations in MMP breakdown enzymes, this leads to an excess of collagen in the extracellular space and hence fibrosis (Fig. 3).

Many cells secrete TGF- $\beta$ as an inactive complex, its activation being precipitated by a number of factors including MMPs and integrins. In health, it appears to play a crucial role in embryogenesis, extracellular matrix homeostasis and maybe in antiatherogenesis. In disease, it regulates the expression and function of all the cells involved in tissue repair and remodeling [68]. Mice overexpressing TGF- $\beta$ have been shown to develop cardiac hypertrophy and interstitial fibrosis [69]. Myocardial TGF- $\beta$ levels have been shown to be elevated in patients with dilated or hypertrophic cardiomyopathy (HCM) [47]. 


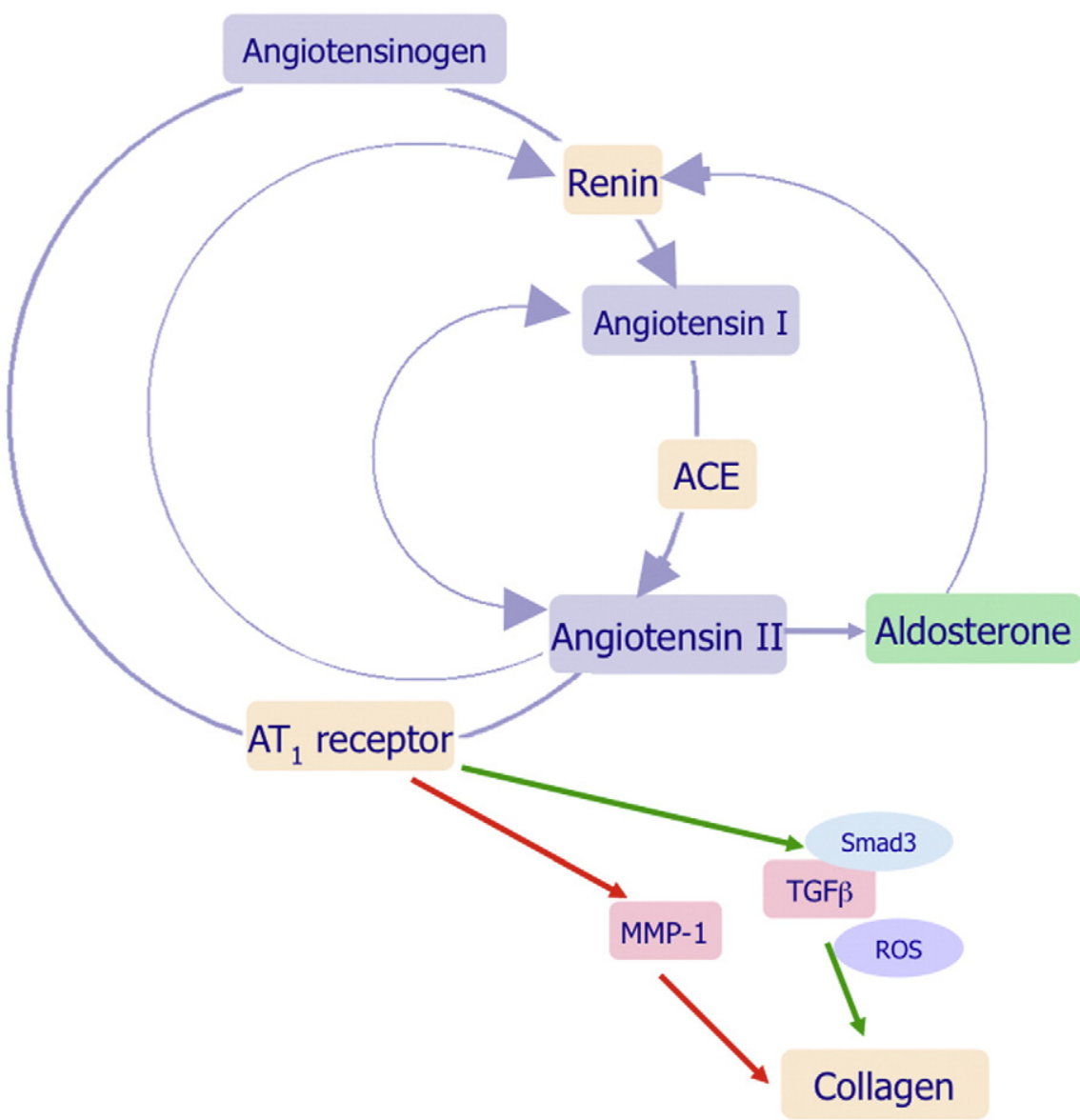

Fig. 3. Main enzymatic steps leading to the synthesis of the renin-angiotensin-aldosterone-synthesis (RAAS) effectors; interactions and feedbacks are marked by blue arrows. Angiotensin II, by binding to the angiotensin II type 1 receptor (AT1), activates the TGFbeta and SMAD3 signaling pathway and decreases the expression and activity of matrix metalloproteinase (MMP)-1. Angiotensin II also stimulates the intracellular generation of reactive oxygen species (ROS) in cardiac fibroblasts, finally contributing to the development of organ fibrosis. Green arrow: stimulatory signal; red arrow: inhibitory signal.

\section{Markers of ongoing myocardial damage: troponins}

Ongoing myocardial damage (OMD) has been proposed as a possible mechanism of cardiac remodeling and disease progression in chronic HF. Independent of the presence of coronary artery disease, OMD produces chronic cardiac troponin (cTn) release in patients with $\mathrm{HF}$, whose plasma levels hold a prognostic value [70]. A recent study reported an association between cTnT release into the coronary circulation (by simultaneous assay of serum cTnT levels in the aortic root and coronary sinus) and the presence and extent of myocardial fibrosis assessed by late gadolinium enhancement at cardiac magnetic resonance in nonischemic patients with HF [71]. Activation of adrenergic signalling pathways [72] and mechanical stress, due to cardiac output impairment and hemodynamic overload during exercise [73], have been proposed as pathophysiological mechanisms responsible for OMD in HF.

It is well known that a relatively large fraction of patients with HF (from $25 \%$ to $45 \%$ ), especially those with clinical history of coronary artery disease, share increased levels of $\mathrm{cTnI}$ and $\mathrm{cTnT}$, even if measured by standard (not highly sensitive) methods [74]. More recent studies $[71,75,76]$ reported that the fraction of HF patients with troponin values above the 99th percentile upper reference population limit (99th URL) greatly increase when the high sensitive immunoassay methods are used for $\mathrm{cTnI}$ and $\mathrm{cTnT}$ measurement. In particular, considering the large population of patients with chronic HF of the ValHeFT study (4053 patients randomized), only $10.4 \%$ of these patients showed measurable cTnT with the standard assay, while this fraction increased up to $92 \%$ when samples were reassessed with a more sensitive method [70]. These premises, together with the recognized prognostic role of increased troponin in HF [70], support the hypothesis that troponinrelated proteolysis could somehow be also implicated in the development of cardiac damage promoting progression to HF. Indeed, it is conceivable that repetitive bouts of ischemia are able to promote cardiomyocyte death, replacement fibrosis, and ventricular remodeling, which in turn can produce a worsening of diastolic and systolic function. In addition, apoptotic cells have been described in the healthy adult heart [77] and cardiomyocytes have been shown to renew in humans [78]. Both processes, to different extent, are likely impaired in HF. At present time, there are no experimental data indicating that during apoptosis troponins are degraded within the cardiomyocytes and released into the interstitial space. There are two potential explanations for the troponin release in the absence of fatal sarcolemmal disruption: 1) cellular release of proteolytic troponin degradation products and 2) troponin leaks from reversibly damaged cardiomyocytes, as an intact nondegraded protein chain $[74,79]$. As these degradation mechanisms have been evaluated only in experimental studies using culture of cardiomyocytes, further studies are needed to evaluate the relevance of these pathophysiological mechanisms in vivo in patients with cardiovascular diseases. Furthermore, it is well known that a small fraction (about 4-8\% of the total) of cTnI and cTnT content of cardiomyocyte is present in the monomeric form in the sarcoplasm, and so this protein fraction may be released in the circulation during a reversible myocardial injury [80]. Mechanical stretch of cardiomyocytes, as it occurs during pressure or volume overload, may activate some intracellular proteases, such as MMPs, which are able degrade cardiac troponin within the cell [81]. Overload-induced stretch at the cardiomyocyte level is sensed by integrins, which are mechanotransducer molecules that link the 
extracellular matrix to the intracellular cytoskeleton [82]. Hence, this mechanism may be involved in the stretch-induced release of troponin and its degradation products [79]. Furthermore, several findings obtained in healthy individuals and even in well-trained athletes after endurance exercise support this hypothesis [83-85]. These findings suggest that the stretch stimulation of viable cardiomyocytes may lead to intact cTnI release. As discussed in detail in other recent reviews [86,87], the increased analytical sensitivity of cTnI and cTnT methods will likely help to spread more light on the process of "non-necrotic" troponin release into the blood and should be considered a powerful tool to monitor the processes related both to physiological renewal and pathologic remodeling of myocardial tissue.

\section{7. “Novel" biomarkers of myocardial fibrosis and remodeling}

\subsection{ST2}

ST2 is a member of the IL-1 receptor superfamily and it exists in two forms, a transmembrane (ST2L) and a soluble one (sST2), which is present in extracellular space as well as in circulation. ST2L is the specific receptor of IL-33, a cytokine generally released by myocytes after myocardial stress (e.g. pressure overload) [88], whose role is to blunt cardiac remodeling and fibrosis [89,90], as well as hypertrophy in mechanically strained tissues [91]. ST2L transduces to the cell the effects of IL-33, while SST2 acts as a decoy receptor and sequesters it, reducing its positive effects. In stress conditions SST2 increases, thus leading to a higher incidence of deleterious cardiac events, including adverse cardiac remodeling.

Due to its functional role, sST2 has been studied in various different cardiac diseases, with a special concern to myocardial infarction and HF, and it has been recently included in the ACCF/AHA guidelines for the management of HF [3]. Recent studies reported that circulating SST2 values correlate with the clinical severity of HF, LV ejection fraction, BNP and NT-proBNP $[43,92]$. The sST2 levels at presentation were higher among patients who died by 1 year. In a multivariable Cox model analysis containing several established clinical and biochemical predictive variables, SST2 remained an independent predictor of mortality and it showed an incremental prognostic value over natriuretic peptides $[43,92]$. In patients with decompensated HF, sST2 plasma concentration in the upper tertile at presentation was a strong and independent predictor of all-cause mortality after one year of follow-up [93]. Similar results have been obtained in acute myocardial infarction, with higher sST2 levels correlating to a more impaired hemodynamic, a worse ischemic profile on admission, and higher mortality rate at one month [94].

Recently sST2 has been studied as a prognostic marker together with troponins and GDF 15. Their combined measurement improved the prognostic information of the patients, independent of NT-proBNP [95], confirming the importance of a multimarker strategy when dealing with risk stratification in HF patients.

\subsection{Galectin-3}

Initially studied as a mediator of cancer growth and progression, galectin-3 is, among lectins, a unique chimera-like galectin, which can interact with several extracellular matrix proteins, carbohydrates and nonglycosylated proteins. Galectin-3 is localized within the cytoplasmic space of several cell types. In particular, macrophages can secrete galectin-3 in the extracellular space and activate resting fibroblasts into a matrix-producing phenotype $[27,96]$.

Sharma and colleagues first reported a causal relationship between galectin-3 and cardiac damage in a rat model overexpressing the murine Ren-2d renin gene [27]. They observed a 5-fold increase in the expression of galectin-3 gene in rats with overt HF, as well as a higher degree of interstitial collagen and galectin-3 protein content, colocalized with macrophage-specific staining, compared to rats with compensated HF and to wild type [97]. They also performed intrapericardial infusion of galectin-3 in healthy rats, observing thereafter a reduction in LV ejection fraction and an increase in collagen content versus placebo. Interestingly, genetic disruption of galectin-3 produced blunted cardiac hypertrophy and dysfunction, after treatment with either angiotensin II infusion or transverse aortic constriction [98].

Although not conclusive, there is some experimental evidence that the RAAS and galectin-3 share some signaling pathways and interplay in the development of cardiac fibrosis. Azibani showed that in hypertensive mice with cardiac hyperaldosteronism, aldosterone elicited a massive macrophage infiltration and an increase in cardiac galectin-3 expression and protein content, especially in the fibrotic areas [99].

As a whole, the abovementioned experimental findings envisage a causative involvement of galectin-3, as a key mediator of maladaptive tissue response to damage, in inflammation and fibrogenesis, and finally in the pathophysiology of cardiac remodeling. Indeed, some human studies have demonstrated a correlation between galectin-3 and circulating markers of ECM metabolism and that galectin-3 elevation is an independent predictor of left ventricular adverse remodeling (defined as a percentage change in the left ventricular end-diastolic volume along a 3-month follow-up) in patients with systolic HF [100,101].

\subsection{Biglycan and decorin}

Biglycan is a small leucine-rich proteoglycan expressed in many tissues in vivo, including the skin, kidney and heart [102]. Several roles of biglycan have been demonstrated: ECM organization, cellular adhesion and migration [103]. Biglycan, together with other small leucine-rich proteins, can bind various collagen types (I, II, III, VI) [104,105] and plays a major role in modulating inflammatory processes by binding Toll-like receptors 2 and 4 [106-108]. Furthermore, in transgenic mice overexpressing human biglycan, the up-regulation of several proteins of the TGF- $\beta$ and nitric oxide family has been described [109]. Given these physiological actions, the role of biglycan in cardiac remodeling has been further investigated, particularly after myocardial infarction. Westermann has demonstrated that biglycan induction is critical in the mechanisms of scar formation, since biglycan knock-out mice showed increased mortality, left ventricular ruptures and HF after experimental myocardial infarction [110]. Moreover, biglycan seems to be secreted in a RAAS dependent manner [111,112] and its secretion could be prevented by AT1 receptor antagonists [112].

Like biglycan, decorin is a proteoglycan that regulates collagen formation and organization by binding to collagens I and III [113,114]. It is expressed by several tissues including the heart, and its concentration rises in cardiovascular diseases such as myocardial infarction and dilated and hypertrophic cardiomyopathy [115]. Decorin has been demonstrated to interact with the TGFB/SMAD2 pathway. Indeed, decorin binds TGFß $[116,117]$ and inhibits its profibrotic effects, thus likely blunting the development of adverse remodeling.

\section{Analytical performance of biomarkers for heart failure: some general considerations}

From an analytical point of view, all the biomarkers suggested in the previous paragraphs are usually measured by means of immunoassay methods. However, only a small part of these biomarkers are measured with immunoassay methods using fully automated platforms (Table 2). For example, considering the 3 groups of biomarkers actually recommended by the most recent international guidelines [3], it is possible to measure BNP, troponins I and T, and galectin-3 with fully automated platforms, while, at present time, sST2, is still measured by an EIA method. Furthermore, even if the first immunoassay methods for B-type natriuretic peptides (i.e., BNP and NT-proBNP) and cardiac troponin I were set up 30 years ago, there is not an international standardization of these methods. Indeed, BNP immunoassay methods actually show systematic differences up to 50\% [118-120], while even a greater bias is 
Table 6

Comparison of analytical performances of galectin-3 assay methods.

\begin{tabular}{|c|c|c|c|c|c|}
\hline \multirow[t]{2}{*}{ Method } & \multirow{2}{*}{$\frac{\mathrm{LoB}}{(\mathrm{ng} / \mathrm{mL})}$} & \multirow{2}{*}{$\frac{\text { LoD }}{(\mathrm{ng} / \mathrm{mL})}$} & \multirow{2}{*}{$\frac{\text { LoQ }}{(\mathrm{ng} / \mathrm{mL})}$} & \multirow[t]{2}{*}{ TAT } & \multirow[t]{2}{*}{ Reference } \\
\hline & & & & & \\
\hline ELISA, Waltham & 0.86 & 1.13 & 0.97 & About $3 \mathrm{~h}$ & Christenson et al. [122] \\
\hline ARCHITECT Platform, Abbott & $0.1-0.3$ & $1.4-2.1$ & $3.0-3.3$ & About $30 \mathrm{~min}$ & La'ulu et al. [123] \\
\hline VIDAS platform, BioMérieux & - & 2.4 & 3.3 & About $30 \mathrm{~min}$ & Vernet et al. [124] \\
\hline
\end{tabular}

LoB: limit of blank; LoD: limit of detection; LoQ: limit of quantitation; TAT: turnaround time.

on average found between cTnI immunoassay methods [121]. As an example, in Table 6 , a comparison between the analytical characteristics of the immunoassay methods for galectin-3 is reported. Even if all the materials and standards used by these laboratory tests are supplied by the same company (BG Medicine, Waltham, MA), these methods show some differences in the analytical performance, as demonstrated by the data reported in Table 6. In particular, the ELISA method shows a longer turnaround time (TAT) than the two automated immunoassays, suggesting that this method has a lower practicability than those using the Architect and VIDAS automated platforms. However, the ELISA method shows an analytical sensitivity similar (if not better) than the two automated systems [122-124].

From a clinical point of view, it is important to note that tissue levels of several biomarkers (including some cytokines, chemokines, tissue proteases, and neuro-hormones, such as noradrenaline, angiotensin II and aldosterone) described in the previous paragraphs could be little (or even not at all) correlated with their respective circulating levels, thus suggesting that the measurement of plasma/serum concentrations of these biomarkers could have little pathophysiological relevance. Furthermore, these substances, if used as biomarkers, are not cardiacspecific, because they are expressed in all human tissues, when an inflammatory process or tissue damage is promoted. As a result, it is not possible, when several organs are together injured, to differentiate the fraction of biomarker circulating levels derived from cardiac tissue or other tissues. This is an important limitation of these biomarkers compared to cardiac troponins and natriuretic peptides, which can be recognized as cardiac specific biomarkers.

\section{Perspectives}

A large number of biomarkers with a plausible biological link with HF pathophysiology, mainly associated with immuno-inflammatory and neurohormonal response to heart damage, have been identified so far [2]. Many of these biomarkers share the ability to define the severity of the ongoing ventricular remodeling process, but often lack of cardiac specificity and levels can be influenced by both systemic inflammatory and infective processes, which occur frequently in HF patients. In this clinical context, a new generation of point-of-care testing (POCT) methods for these HF biomarkers, characterized by an improved degree of sensitivity and imprecision, could be utilized in inpatients, outpatients and emergency department settings to aid in the rapid diagnosis, risk and management of patients presenting with symptoms consistent with HF. In particular, the implementation of POCT methods for BNP/NT-proBNP into home-monitoring strategies could help patients and physicians to avoid unnecessary hospitalization or anticipate admission in the clinical ward when it is actually needed [125]. Of course, for the greater part of these novel biomarkers as well as new methodologies, usefulness in driving the clinical and therapeutic decision-making process is still to be proved.

In the recent years, some imaging techniques (cardiac magnetic resonance, cardiac ultrasound with backscatter analysis, positron emission tomography) have been also developed for in vivo tissue characterization. In particular, cardiac magnetic resonance by means of the late gadolinium enhancement technique resulted in a good means for detection of gross myocardial fibrosis in HF [41,126]. In addition, other cardiac magnetic resonance techniques, as T1 mapping, are giving encouraging results for definition and quantification of interstitial fibrosis [127], potentially providing early information on the ongoing remodeling process. Integration of circulating biomarkers with those derived from imaging techniques, as cardiac magnetic resonance, may represent an innovative and effective strategy for a thorough definition of the remodeling process.

Despite clinical guidelines [3] do not routinely recommend endomyocardial biopsies for the management of HF due to an unfavorable risk/benefit ratio, in the clinical setting there is an unmet need for a specific, accurate, and effective biomarker of the ongoing remodeling process in HF. Besides natriuretic peptides and troponins, up-to-date soluble ST2 and galectin-3 are the most studied remodeling biomarkers in the clinical setting but have not yet reached the highest class of recommendation/evidences. Indeed, further studies are needed, in selected, large populations, to test the efficacy of these and other new markers preferably within a multi-marker strategy for patient management, including diagnostic information provided by cardiovascular imaging [128]. Finally, the development of more automated, easily accessible assays, together with a careful evaluation of analytical and clinical performances as well as of their cost-effectiveness, is mandatory for a transfer to routine practices.

\section{References}

[1] Braunwald E, Bristow MR. Congestive heart failure: 50 years of progress. Circulation 2000;102(20 Suppl 4):IV14-23

[2] Emdin M, Vittorini S, Passino C, Clerico A. Old and new biomarkers of heart failure Eur J Heart Fail 2009;11:331-5.

[3] Yancy CW, Jessup M, Bozkurt B. ACCF/AHA guideline for the management of heart failure: a report of the American College of Cardiology Foundation/American Heart Association Task Force on practice guidelines. J Am Coll Cardiol 2013;62:e147-239.

[4] Wang TJ. Assessing the role of circulating, genetic, and imaging biomarkers in cardiovascular risk prediction. Circulation 2011;123:551-65.

[5] Hlatky MA, Greenland P, Arnett DK, Ballantyne CM, Criqui MH, Elkind MS, et al. Criteria for evaluation of novel markers of cardiovascular risk: a scientific statement from the American Heart Association. Circulation 2009;119:2408-16.

[6] Meta-analysis Global Group in Chronic Heart Failure (MAGGIC. The survival of patients with heart failure with preserved or reduced left ventricular ejection fraction: an individual patient data meta-analysis. Eur Heart J 2012;33:1750-7.

[7] Yusuf S, Pfeffer MA, Swedberg K, Granger CB, Held P, McMurray JJ, et al. Effects of candesartan in patients with chronic heart failure and preserved left-ventricular ejection fraction: the CHARM-Preserved Trial. Lancet 2003;362:777-81.

[8] Pitt B, Pfeffer MA, Assmann SF, Boineau R, Anand IS, Claggett B, et al. TOPCAT investigators. Spironolactone for heart failure with preserved ejection fraction. N Engl J Med 2014;370:1383-92.

[9] Felker GM, Thompson RE, Hare JM, Hruban RH, Clemetson DE, Howard DL, et al. Underlying causes and long-term survival in patients with initially unexplained cardiomyopathy. N Engl J Med 2000;342:1077-84.

[10] Swynghedauw B. Phenotypic plasticity of adult myocardium: molecular mechanisms. J Exp Biol 2006;209:2320-7.

[11] Unverferth DV, Baker PB, Swift SE, Chaffee R, Fetters JK, Uretsky BF, et al. Extent of myocardial fibrosis and cellular hypertrophy in dilated cardiomyopathy. Am J Cardiol 1986:57:816-20.

[12] Weber KT, Brilla CG. Pathological hypertrophy and cardiac interstitium. Fibrosis and renin-angiotensin-aldosterone system. Circulation 1991;83:1849-65.

[13] Beltrami CA, Finato N, Rocco M, Feruglio GA, Puricelli C, Cigola E, et al. The cellular basis of dilated cardiomyopathy in humans. J Mol Cell Cardiol 1995;27:291-305.

[14] Neglia D, Parodi O, Gallopin M, Sambuceti G, Giorgetti A, Pratali L, et al. Myocardial blood flow response to pacing tachycardia and to dipyridamole infusion in patients with dilated cardiomyopathy without overt heart failure. A quantitative assessment by positron emission tomography. Circulation 1995;92:796-804.

[15] Neglia D, Michelassi C, Trivieri MG, Sambuceti G, Giorgetti A, Pratali L, et al. Prognostic role of myocardial blood flow impairment in idiopathic left ventricular dysfunction. Circulation 2002;105:186-93.

[16] Lionetti V, Guiducci L, Simioniuc A, Aquaro GD, Simi C, De Marchi D, et al. Mismatch between uniform increase in cardiac glucose uptake and regional contractile 
dysfunction in pacing-induced heart failure. Am J Physiol Heart Circ Physiol 2007; 293:H2747-56.

[17] Emdin M, Passino C, Prontera C, Iervasi A, Ripoli A, Masini S, et al. Cardiac natriuretic hormones, neuro-hormones, thyroid hormones and cytokines in normal subjects and patients with heart failure. Clin Chem Lab Med 2004;42:627-36.

[18] Redfield MM, Jacobsen SJ, Burnett Jr JC, Mahoney DW, Bailey KR, Rodeheffer RJ. Burden of systolic and diastolic ventricular dysfunction in the community: appreciating the scope of the heart failure epidemic. JAMA 2003;289:194-202.

[19] Wynn TA, Ramalingam TR. Mechanisms of fibrosis: therapeutic translation for fibrotic disease. Nat Med 2012;18:1028-40.

[20] Borthwick LA, Wynn TA, Fisher AJ. Cytokine mediated tissue fibrosis. Biochim Biophys Acta 1832;2013:1049-60.

[21] Hartupee J, Mann DL. Positioning of inflammatory biomarkers in the heart landscape. J Cardiovasc Trans Res 2013;6:485-92.

[22] Bozkurt B, Mann DL, Deswal A. Biomarkers of inflammation in heart failure. Heart Fail Rev 2010;15:331-41.

[23] Levine B, Kalman J, Mayer L, Fillit HM, Packer M. Elevated circulating levels of tumor necrosis factor in severe chronic heart failure. New Engl J Med 1990;223: 236-41.

[24] Glezeva N, Baugh JA. Role of inflammation in the pathogenesis of heart failure with preserved ejection fraction and its potential as a therapeutic target. Heart Fail Rev doi: 10.1007/s10741-013-9405-8.

[25] Kuwahara F, Kai H, Tokuda K, Takeya M, Takeshita A, Egashira K, et al. Hypertensive myocardial fibrosis and diastolic dysfunction: another model of inflammation? Hypertension 2004;43:739-45.

[26] Kai H, Kuwahara F, Tokuda K, Imaizumi T. Diastolic dysfunction in hypertensive hearts: roles of perivascular inflammation and reactive myocardial fibrosis. Hypertens Res 2005;28:483-90.

[27] Sharma UC, Pokharel S, van Brakel TJ, van Berlo JH, Cleutjens JP, Schroen B, et al. Galectin-3 marks activated macrophages in failure-prone hypertrophied hearts and contributes to cardiac dysfunction. Circulation 2004;110:3121-8.

[28] Inoue K, Kodama T, Daida H. Pentraxin 3: a novel biomarker for inflammatory cardiovascular disease. Int J Vasc Med 2012;2012:657025.

[29] Vasan RS, Sullivan LM, Roubenoff R, Dinarello CA, Harris T, Benjamin EJ, et al. Inflammatory markers and risk of heart failure in elderly subjects without prior myocardial infarction: the Framingham Heart Study. Circulation 2003;107:1486-91.

[30] Torre-Amione G, Kapadia S, Benedict CR, Oral H, Young JB, Mann DL. Proinflammatory cytokine levels in patients with depressed left ventricular ejection fraction: a report from the studies of left ventricular dysfunction (SOLVD). J Am Coll Cardiol 1996;27:1201-6.

[31] Rauchhaus M, Doehner W, Francis DP, Davos C, Kemp M, Liebenthal C, et al. Plasma cytokine parameters and mortality in patients with chronic heart failure. Circulation 2000;102:3060-7.

[32] Deswal A, Petersen NJ, Feldman AM, Young JB, White BG, Mann DL. Cytokines and cytokine receptors in advanced heart failure: an analysis of the cytokine database from the Vesnarinone Trial (VEST). Circulation 2001;103:2055-9.

[33] Dunlay SM, Weston SA, Redfield MM, Killian JM, Roger VL. Tumor necrosis factoralpha and mortality in heart failure: a community study. Circulation 2008;118: 625-31.

[34] Anand IS, Kempf T, Rector TS, Tapken H, Allhoff T, Jantzen F, et al. Serial measurement of growth-differentiation factor-15 in heart failure: relation to disease severity and prognosis in the Valsar-tan Heart Failure Trial. Circulation 2010;122: $1387-95$.

[35] Kempf T, Horn-Wichmann R, Brabant G, Peter T, Allhoff T, Klein G, et al. Circulating concentrations of growth-differentiation factor 15 in apparently healthy elderly individuals and patients with chronic heart failure as assessed by a new immunoradiometric sandwich assay. Clin Chem 2007:53:284-91.

[36] Stahrenberg R, Edelmann F, Mende M, Kockskamper A, Dungen HD, Luers C, et al. The novel biomarker growth differentiation factor 15 in heart failure with normal ejection fraction. Eur J Heart Fail 2010;12:1309-16.

[37] Santhanakrishnan R, Chong JP, Ng TP, Ling LH, Sim D, Leong KT, et al. Growth differentiation factor 15, ST2, high-sensitivity troponin T, and N-terminal pro brain natriuretic peptide in heart failure with preserved vs. reduced ejection fraction. Eur J Heart Fail 2012;14:1338-47.

[38] Chin BS, Conway DS, Chung NA, Blann AD, Gibbs CR, Lip GY. Interleukin-6, tissue factor and von Willebrand factor in acute decompensated heart failure: relationship to treatment and prognosis. Blood Coagul Fibrinolysis 2003;14:515-21.

[39] Mueller C, Laule-Kilian K, Christ A, Brunner-La Rocca HP, Perruchoud AP. Inflammation and long-term mortality in acute congestive heart failure. Am Heart J 2006; 151:845-50.

[40] van Kimmenade RR, Januzzi Jr JL, Ellinor PT, Sharma UC, Bakker JA, Low AF, et al. Utility of aminoterminal pro-brain natriuretic peptide, galectin-3, and apelin for the evaluation of patients with acute heart failure. J Am Coll Cardiol 2006;48:1217-24.

[41] Villacorta H, Masetto AC, Mesquita ET. C reactive protein: an inflammatory marker with prognostic value in patients with decompensated heart failure. Arq Bras Cardiol 2007:88:585-9.

[42] Januzzi Jr JL, Peacock WF, Maisel AS, Chae CU, Jesse RL, Baggish AL, et al. Measurement of the interleukin family member ST2 in patients with acute dyspnea: results from the PRIDE (Pro-Brain Natriuretic Peptide Investigation of Dyspnea in the Emergency Department) study. J Am Coll Cardiol 2007;50:607-13.

[43] Rehman SU, Mueller T, Januzzi Jr JL. Characteristics of the novel interleukin family biomarker ST2 in patients with acute heart failure. J Am Coll Cardiol 2008;52: 1458-65.

[44] Shah RV, Chen-Tournoux AA, Picard MH, van Kimmenade RR, Januzzi JL. Galectin-3, cardiac structure and function, and long-term mortality in patients with acutely decompensated heart failure. Eur J Heart Fail 2010;12:826-32.
[45] Lindsay MM, Dunn FG. Biochemical evidence of myocardial fibrosis in veteran endurance athletes. Br J Sports Med 2007;41:447-52.

[46] Mewton N, Liu CY, Croisille P, Bluemke D, Lima JAC. Assessment of myocardial fibrosis with cardiovascular magnetic resonance. J Am Coll Cardiol 2011;57:891-903.

[47] Pauschinger M, Knopf D, Petschauer S, Doerner A, Poller W, Schwimmbeck PL, et al. Dilated cardiomyopathy is associated with significant changes in collagen type I/II ratio. Circulation 1999;99:2750-6.

[48] Jensen LT, Host NB. Collagen: scaffold for repair or execution. Cardiovasc Res 1997; 33:535-9.

[49] Malemud CJ. Matrix metalloproteinases (MMPs) in health and disease: an overview. Front Biosci 2006;11:1696-701.

[50] Risteli J, Elomaa I, Niemi S, Novamo A, Risteli L. Radioimmunoassay for the pyridinoline cross-linked carboxy-terminal telopeptide of type I collagen: a new serum marker of bone collagen degradation. Clin Chem 1993;39:635-40.

[51] Klappacher G, Franzen P, Haab D, Mehrabi M, Binder M, Plesch K, et al. Measuring extracellular matrix turnover in the serum of patients with idiopathic or ischemic dilated cardiomyopathy and impact on diagnosis and prognosis. Am J Cardiol 1995; 75:913-8.

[52] Izawa H, Murohara T, Nagata K, Isobe S, Asano H, Amano T, et al. Mineralocorticoid receptor antagonism ameliorates left ventricular diastolic dysfunction and myocardial fibrosis in mildly symptomatic patients with idiopathic dilated cardiomyopathy: a pilot study. Circulation 2005;112:2940-5.

[53] Querejeta R, López B, González A, Sánchez E, Larman M, Martínez Ubago JL, et al. Increased collagen type I synthesis in patients with heart failure of hypertensive origin: relation to myocardial fibrosis. Circulation 2004;110:1263-8.

[54] Agarwal I, Glazer NL, Barasch E, Biggs ML, Djousse L, Fitzpatrick AL, et al. Fibrosisrelated biomarkers and incident cardiovascular disease in older adults: the cardiovascular health study. Circ Arrhythm Electrophysiol 2014;7:583-9.

[55] Barasch E, Gottdiener JS, Aurigemma G, Kitzman DW, Han J, Kop WJ, et al. The relationship between serum markers of collagen turnover and cardiovascular outcome in the elderly: the Cardiovascular Health Study. Circ Heart Fail 2011;4:733-9.

[56] Cicoira M, Rossi A, Bonapace S, Zanolla L, Golia G, Franceschini L, et al. Independent and additional prognostic value of aminoterminal propeptide of type IIl procollagen circulating levels in patients with chronic heart failure. J Card Fail 2004; 10:403-11.

[57] Manhenke C, Orn S, Squire I, Radauceanu A, Alla F, Zannad F, et al. The prognostic value of circulating markers of collagen turnover after acute myocardial infarction. Int J Cardiol 2011;150:277-82.

[58] Kitahara T, Takeishi Y, Arimoto T, Niizeki T, Koyama Y, Sasaki T, et al. Serum carboxy-terminal telopeptide of type I collagen (ICTP) predicts cardiac events in chronic heart failure patients with preserved left ventricular systolic function. Circ J 2007;71:929-35.

[59] López B, González A, Querejeta R, Larman M, Díez J. Alterations in the pattern of collagen deposition may contribute to the deterioration of systolic function in hypertensive patients with heart failure. J Am Coll Cardiol 2006;48:89-96.

[60] Sundström J, Evans JC, Benjamin EJ, Levy D, Larson MG, Sawyer DB, et al. Relations of plasma total TIMP-1 levels to cardiovascular risk factors and echocardiographic measures: the Framingham heart study. Eur Heart J 2004;25:1509-16.

[61] Ahmed SH, Clark LL, Pennington WR, Webb CS, Bonnema DD, Leonardi AH, et al. Matrix metalloproteinases/tissue inhibitors of metalloproteinases: relationship between changes in proteolytic determinants of matrix composition and structural, functional, and clinical manifestations of hypertensive heart disease. Circulation 2006;113:2089-96.

[62] Eschalier R, Rossignol P, Kearney-Schwartz A, Adamopoulos C, Karatzidou K, Fay R, et al. Features of cardiac remodeling, associated with blood pressure and fibrosis biomarkers, are frequent in subjects with abdominal obesity. Hypertension 2014 63:740-6.

[63] Zannad F, Alla F, Dousset B, Perez A, Pitt B. Limitation of excessive extracellular matrix turnover may contribute to survival benefit of spironolactone therapy in patients with congestive heart failure: insights from the randomized aldactone evaluation study (RALES). Rales Investigators. Circulation 2000;102:2700-6.

[64] Fontaine V, Jacob MP, Houard X, Rossignol P, Plissonnier D, Angles-Cano E, et al. Involvement of the mural thrombus as a site of protease release and activation in human aortic aneurysms. Am J Pathol 2002;161:1701-10.

[65] Seeland U, Schäffer A, Selejan S, Hohl M, Reil JC, Müller P, et al. Effects of AT1- and beta-adrenergic receptor antagonists on TGF-beta1-induced fibrosis in transgenic mice. Eur J Clin Invest 2009;39:851-9.

[66] Brilla CG. Renin-angiotensin-aldosterone system and myocardial fibrosis. Cardiovasc Res 2000;47:1-3.

[67] Watanabe T, Barker TA, Berk BC. Angiotensin II and the endothelium: diverse signals and effects. Hypertension 2005;45:163-9.

[68] Dobaczewski M, Chen W, Frangogiannis NG. Transforming growth factor (TGF)- $\beta$ signaling in cardiac remodeling. J Mol Cell Cardiol 2011;51:600-6.

[69] Rosenkranz S, Flesch M, Amann K, Haeuseler C, Kilter H, Seeland U, et al. Alterations of beta-adrenergic signaling and cardiac hypertrophy in transgenic mice overexpressing TGF-beta(1). Am J Physiol Heart Circ Physiol 2002;283:H1253-62.

[70] Latini R, Masson S, Anand IS, Missov E, Carlson M, Vago T, et al. Prognostic value of very low plasma concentrations of troponin $\mathrm{T}$ in patients with stable chronic heart failure. Circulation 2007;116:1242-9.

[71] Takashio S, Yamamuro M, Uemura T, Utsunomiya D, Morita K, Izumiya Y, et al. Correlation between extent of myocardial fibrosis assessed by cardiac magnetic resonance and cardiac troponin $\mathrm{T}$ release in patients with nonischemic heart failure. Am J Cardiol 2014;113:1697-704.

[72] Todd GL, Baroldi G, Pieper GM, Clayton FC, Eliot RS. Experimental catecholamine induced myocardial necrosis. Morphology, quantification and regional distribution of acute contraction band lesions. J Mol Cell Cardiol 1985;17:317-38. 
[73] Feng J, Schaus BJ, Fallavolita JA, Lee TC, Canty Jr JM. Preload induces troponin I degradation independently of myocardial ischemia. Circulation 2001;103:2035-7.

[74] Hessel MH, Michielsen EC, Atsma DE, Schalij MJ, van der Valk EJ, Bax WH, et al. Release kinetics of intact and degraded troponin I and $\mathrm{T}$ after irreversible cell damage. Exp Mol Pathol 2008;85:90-2.

[75] Wu AH. Interpretation of high sensitivity cardiac troponin I results: reference to biological variability in patients who present to the emergency room with chest pain: case report series. Clin Chim Acta 2009;401:170-4.

[76] White HD. Will new higher-precision troponins lead to clarify or confusion? Curr Opin Cradiol 2008;23:292-5

[77] Morrow DA, Cannon CP, Jesse RL, Newby LK, Ravkilde J, Storrow AB, et al. National Academy of Clinical Biochemistry Laboratory Medicine Practice Guidelines: clinical characteristics and utilization of biochemical markers in acute coronary syndromes. Clin Chem 2007;53:552-74.

[78] Bergmann O, Bhardwaj RD, Bernard S, Zdunek S, Barnabé-Heider F, Walsh S, et al. Evidence for cardiomyocyte renewal in humans. Science 2009;324:98-102.

[79] Hessel MH, Atsma DE, van der Valk EJ, Bax WH, Schalij MJ, van der Laarse A. Release of cardiac troponin I from viable cardiomyocytes is mediated by integrin stimulation. Pflugers Arch 2008:455:979-86.

[80] Hickman PE, Potter JM, Aroney C, et al. Cardiac troponin may be released by ischemia alone, without necrosis. Clin Chim Acta 2010;411:318-32.

[81] Wang W, Schulze CJ, Suarez-Pinzon WL, Dyck JR, Sawicki G, Schulz R. Intracellular action of matrix metalloproteinase-2 accounts for acute myocardial ischemia and reperfusion injury. Circulation 2002;106:1543-9.

[82] Shyy JY, Chien S. Role of integrins in cellular responses to mechanical stress and adhesion. Curr Opin Cell Biol 1997;9:707-13.

[83] Herrmann M, Scharhag J, Miclea M, Urhausen A, Herrmann W, Kindermann W. Post-race kinetics of cardiac troponin $\mathrm{T}$ and I and $\mathrm{N}$-terminal pro-brain natriuretic peptide in marathon runners. Clin Chem 2003;49:831-4.

[84] Roth HJ, Leithäuser RM, Doppelmayr H, et al. Cardiospecificity of the 3rd generation cardiac troponin $\mathrm{T}$ assay during and after a $216 \mathrm{~km}$ ultra-endurance marathon run in Death Valley. Clin Res Cardiol 2007;96:359-64.

85] Middleton N, George K, Whyte G, Gaze D, Collinson P, Shave R. Cardiac troponin release is stimulated by endurance exercise in healthy humans. J Am Coll Cardiol 2008;52:1813-4.

[86] Giannoni A, Giovannini S, Clerico A. Measurement of circulating concentrations of cardiac troponin I and T in healthy subjects: a tool for monitoring myocardial tissue renewal? Clin Chem Lab Med 2009;47:1167-77.

[87] Clerico A, Giannoni A, Prontera T, Giovannini S. High-sensitivity troponin: a new toll for pathophysiological investigation and clinical practice. Adv Clin Chem 2009;49:1-30.

[88] Broch K, Ueland T, Nymo SH, Kjekshus J, Hulthe J, Muntendam P, et al. Soluble ST2 is associated with adverse outcome in patients with heart failure of ischaemic aetiology. Eur J Heart Fail 2012;14:268-77.

[89] Sanada S, Hakuno D, Higgins LJ, Schreiter ER, McKenzie AN, Lee RT, et al. Expression and regulation of ST2, an interleukin-1 receptor family member, in cardiomyocytes and myocardial infarction. Circulation 2002;3:2961-6.

[90] Weir RA, Miller AM, Murphy GE, Clements S, Steedman T, Connell JM, et al. Serum soluble ST2: a potential novel mediator in left ventricular and infarct remodeling after acute myocardial infarction. J Am Coll Cardiol 2010;55:243-50

[91] Ky B French B, McCloskey K, Rame JE, McIntosh E, Shahi P, et al. High-sensitivity ST2 for prediction of adverse outcomes in chronic heart failure. Circ Heart Fail 2011;4:180-7.

[92] Shah RV, Chen-Tournoux AA, Picard MH, van Kimmenade RR, Januzzi JL. Serum levels of the interleukin-1 receptor family member ST2, cardiac structure and function, and long-term mortality in patients with acute dyspnea. Circ Heart Fail 2009; 2:311-9.

[93] Mueller T, Dieplinger B, Gegenhuber A, Poelz W, Pacher R, Haltmayer M. Increased plasma concentrations of soluble ST2 are predictive for 1-year mortality in patients with acute destabilized heart failure. Clin Chem 2008;54:752-6.

[94] Shimpo M, Morrow DA, Weinberg EO, Sabatine MS, Murphy SA, Antman EM, et al. Serum levels of the interleukin-1 receptor family member ST2 predict mortality and clinical outcome in acute myocardial infarction. Circulation 2004;109:2186-90.

[95] Gaggin HK, Szymonifka J, Bhardwaj A, Belcher A, De Berardinis B, Motiwala S, et al. Head-to-head comparison of serial soluble ST2, growth differentiation factor-15, and highly-sensitive troponin $\mathrm{T}$ measurements in patients with chronic heart failure. JACC Heart Fail 2014;2:65-72.

[96] Henderson NC, Mackinnon AC, Farnworth SL, Poirier F, Russo FP, Iredale JP, et al. Galectin-3 regulates myofibroblast activation and hepatic fibrosis. Proc Natl Acad Sci U S A 2006;103:5060-5.

97] Schroen B, Heymans S, Sharma U, Blankesteijn WM, Pokharel S, Cleutjens JP, et al. Thrombospondin-2 is essential for myocardial matrix integrity: increased expression identifies failure-prone cardiac hypertrophy. Circ Res 2004;95:515-22.

[98] Yu L, Ruifrok WP, Meissner M, Bos EM, van Goor H, Sanjabi B, et al. Genetic and pharmacological inhibition of galectin-3 prevents cardiac remodeling by interfering with myocardial fibrogenesis. Circ Heart Fail 2013;6:107-17.

[99] Azibani F, Benard L, Schlossarek S, Merval R, Tournoux F, Fazal L, et al. Aldosterone inhibits antifibrotic factors in mouse hypertensive heart. Hypertension 2012;59: 1179-87.

[100] Lok DJ, Lok SI, Bruggink-André de la Porte PW, Badings E, Lipsic E, van Wijngaarden ], et al. Galectin-3 is an independent marker for ventricular remodeling and mortality in patients with chronic heart failure. Clin Res Cardiol 2013;102:103-10.
[101] Lin YH, Lin LY, Wu YW, Chien KL, Lee CM, Hsu RB, et al. The relationship between serum galectin-3 and serum markers of cardiac extracellular matrix turnover in heart failure patients. Clin Chim Acta 2009;409:96-9.

[102] Wegrowski Y, Pillarisetti J, Danielson KG, Suzuki S, Iozzo RV. The murine biglycan: complete cDNA cloning, genomic organization, promoter function, and expression. Genomics 1995;30:8-17.

[103] Merline R, Schaefer RM, Schaefer L. The matricellular functions of small leucinerich proteoglycans (SLRPs). J Cell Commun Signal 2009;3:323-35.

[104] Douglas T, Heinemann S, Bierbaum S, Scharnweber D, Worch H. Fibrillogenesis of collagen types I, II, and III with small leucine-rich proteoglycans decorin and biglycan. Biomacromolecules 2006;7:2388-93.

[105] Wiberg C, Hedbom E, Khairullina A, Lamande SR, Oldberg A, Timpl R, et al. Biglycan and decorin bind close to the n-terminal region of the collagen VI triple helix. J Biol Chem 2001;276:18947-52.

[106] Chen S, Birk DE. The regulatory roles of small leucine-rich proteoglycans in extracellular matrix assembly. FEBS J 2013;280:2120-37.

[107] Song R, Zeng Q, Ao L, Yu JA, Cleveland JC, Zhao KS. Biglycan induces the expression of osteogenic factors in human aortic valve interstitial cells via Toll-like receptor-2. Arterioscler Thromb Vasc Biol 2012;32:2711-20.

[108] Schaefer L, Babelova A, Kiss E, Hausser HJ, Baliova M, Krzyzankova M, et al. The matrix component biglycan is proinflammatory and signals through Toll-like receptors 4 and 2 in macrophages. J Clin Invest 2005;115:2223-33.

[109] Bereczki E, Gonda S, Csont T, Korpos E, Zvara A, Ferdinandy P, et al. Overexpression of biglycan in the heart of transgenic mice: an antibody microarray study. J Proteome Res 2007:6:854-61.

[110] Westermann D, Mersmann J, Melchior A, Freudenberger T, Petrik C, Schaefer L, et al. Biglycan is required for adaptive remodeling after myocardial infarction. Circulation 2008; 117:1269-76.

[111] Zimmermann R, Kastens J, Linz W, Wiemer G, Scholkens BA, Schaper J. Effect of long-term ACE inhibition on myocardial tissue in hypertensive stroke-prone rats. J Mol Cell Cardiol 1999;31:1447-56.

[112] Ahmed MS, Øie E, Vinge LE, Yndestad A, Andersen GGØ, Andersson Y, et al. Induc tion of myocardial biglycan in heart failure in rats - an extracellular matrix component targeted by AT1 receptor antagonism. Cardiovasc Res 2003;60:557-68.

[113] Brown DC, Vogel KG. Characteristics of the in vitro interaction of a small proteoglycan (PG II) of bovine tendon with type I collagen. Matrix 1989;9:468-78.

[114] Thieszen SL, Rosenquist TH. Expression of collagens and decorin during aortic arch artery development: implications for matrix pattern formation. Matrix Biol 1995; $14: 573-82$.

[115] Hwang JJ, Allen PD, Tseng GC, Lam CW, Fananapazir L, Dzau VJ, et al. Microarray gene expression profiles in dilated and hypertrophic cardiomyopathic end-stage heart failure. Physiol Genomics 2002;10:31-44

[116] Hao J, Ju H, Zhao S, Junaid A, Scammell-La Fleur T, Dixon IM. Elevation of expression of Smads 2, 3, and 4, decorin and TGF-beta in the chronic phase of myocardial infarct scar healing. J Mol Cell Cardiol 1999;31:667-78.

[117] Jahanyar J, Joyce DL, Southard RE, Loebe M, Noon GP, Koerner MM, et al. Decorinmediated transforming growth factor-inhibition ameliorates adverse cardiac remodeling. J Heart Lung Transplant 2007;26:34-40.

[118] Prontera C, Zaninotto M, Giovannini S, Zucchelli GC, Pilo A, Sciacovelli L, et al. Proficiency testing project for brain natriuretic peptide (BNP) and the N-terminal part of the propeptide of BNP (NT-proBNP) immunoassays: the CardioOrmoCheck study. Clin Chem Lab Med 2009;47:762-8.

[119] Clerico A, Zaninotto M, Prontera C, Giovannini S, Ndreu R, Franzini M, et al. State of the art of BNP and NT-proBNP immunoassays: the CardioOrmoCheck study. Clin Chim Acta 2012;414:112-9.

[120] Franzini M, Masotti S, Prontera C, Ripoli A, Passino C, Giovannini S, et al. Systematic differences between BNP immunoassays: comparison of methods using standard protocols and quality control materials. Clin Chim Acta 2013;424:287-91.

[121] Tate JR, Bunk DM, Christenson RH, Katrukha A, Noble JE, Porter RA, et al Standardisation of cardiac troponin I measurement: past and present. Pathology 2010;42:402-8.

[122] Christenson $\mathrm{RH}$, Duh $\mathrm{SH}, \mathrm{Wu} \mathrm{AH}$, Smith A, Abel G, deFilippi $\mathrm{CR}$, et al. Multi-cente determination of galectin-3 assay performance characteristics: anatomy of a novel assay for use in heart failure. Clin Biochem 2010;43:683-90.

[123] La'ulu SL, Apple FS, Murakami MM, Ler R, Roberts WL, Straseski JA. Performance of the ARCHITECT galectin-3 assay. Clin Biochem 2013;46:1-2.

[124] Vernet MA, Brevet AM, Broquedis P, et al. Performance evaluation of VIDAS galectin-3 assay. EUROMEDLAB Milano; 2013 [Abstract PW153].

[125] Christenson ES, Collinson PO, Defilippi CR, Christenson RH. Heart failure biomarkers at point-of-care: current utilization and future potential. Expert Rev Mol Diagn 2014;14:185-97.

[126] Masci PG, Barison A, Aquaro GD, Pingitore A, Mariotti R, Passino C, et al. Myocardia delayed enhancement in paucisymptomatic nonischemic dilated cardiomyopathy. Int J Cardiol 2012;157:43-7.

[127] Flett AS, Hayward MP, Ashworth MT, Hansen MS, Taylor AM, Elliott PM, et al. Equilibrium contrast cardiovascular magnetic resonance for the measurement of diffuse myocardial fibrosis: preliminary validation in humans. Circulation 2010;122: $138-44$.

[128] Jaffe AS. Key issues in the developing synergism between cardiovascular imaging and biomarkers. Clin Chem 2008:54:1432-42. 